\title{
The Constitution and Synthesis of Thyroxine.
}

$A^{B O L T}$ a year ago we releffed to the work of Harington on the isolatipar the active principle of the thyroid gland and thedbnstitution and synthesis of its first degyadation product, desiodo-thyroxine (NArURe, July f0, 11066, vol. 118, p. 65). A recent paper by Harington and Barger now completes this important piece of work by proving the constitution of thyroxine itself and describing a method for its synthesis (C. R. Harington and $O$. Barger, Biochem. Journ., 1927, vol. 21, p. 169). The formula for the compound, as suggested by the previous work and proved in the present research, shows that it is a tetra-iodo derivativo of the $p$-hydroxyphenyl ether of tyrosine :

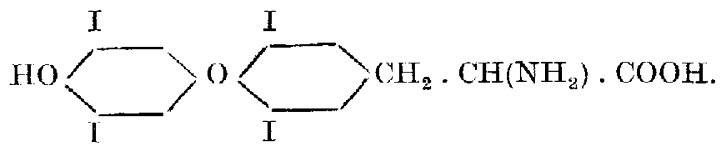

Prcvious work had proved the constitution of desiodothyroxin and its synthesis had been accomplished: the problem remaining was the position of the four iodine atoms in the molecule and their insertion by synthesis. Three considerations made it appear probable that the iodine atoms ocoupied the positions given in the above formula : first, on fusing thyroxine with potash at a high temperature in the absence of oxygen, products were obtained exhibiting pyrogallot reactions, suggesting the presence of $3: 4: 5$ trihydroxy benzene derivatives; secondly, nitrous acid and ammonia gave a colour reaction charactoristic of benzone derivatives containing two iodine atoms in the ortho position to a hydroxyl or amino group ; thirdly, on gonoral grounds it appears probable that thyroxine is synthesised in Nature from tyrosine, through the coupling of two molecules of $3: 5$ diiodotyrosine with the loss of one side-chain.

Direct iodination of dosiodothyroxine resulted in the uptake of two iodine atoms only, so that the introduction of the other two had to be effected before the phenylether synthesis was carried out. Several attempts were made to effect the synthesis, from compounds containing two iodine atoms or other easily replaceable groups in the required positions, of the body $\mathrm{CH}_{3} \mathrm{O} \cdot \mathrm{C}_{6} \mathrm{H}_{2} \mathrm{I}_{2} . \mathrm{O} \cdot \mathrm{C}_{6} \mathrm{H}_{2} \mathrm{I}_{2}$. COOT obtained by the methylation and subsequent oxidation of thyroxine, but without success.

Finally, however, a method was worked out, and the synthetic formation of this methylated oxidation product of thyroxine definitely proved the constitution of the lattcr. Quinol monomethyl ether was condensed with $3: 4: 5$ triiodonitrobenzene, to give $3: 5$ diiodo $-4-\left(4^{\prime}\right.$ methoxyphenoxy) nitrobenzene:
$\mathrm{CH}_{8} \mathrm{O} \cdot \mathrm{C}_{6} \mathrm{H}_{4} \cdot \mathrm{O} \cdot \mathrm{C}_{6} \mathrm{H}_{2} \mathrm{I}_{2} \cdot \mathrm{NO}_{2}$ (the $\mathrm{NO}_{2}$ group having a powerful mobilising effect on the halogen atom in the para position). This compound was then reduced to the aniline and the latter converted, by Sandmeyer's reaction, into the nitrile. The nitrilo, boiled with hydriodic and acetic acids underwent simultareous domethylation and hydrolysis, yielding the compound: $\mathrm{HO} . \mathrm{C}_{6} \mathrm{H}_{4} \cdot \mathrm{O} \cdot \mathrm{C}_{6} \mathrm{H}_{2} \mathrm{I}_{2} . \mathrm{COOH}$; on addition of iodine in potassium iodide to a solution of the acid in concentrated ammonia, iodine was rapidly taken up, the uptake ceasing abruptly at two mole. cules. On methylation an acid, identical in every respect with that obtained by the methylation and oxidation of thyroxine, was produced. Theso oxperiments thus settled the orientation of the iodine atoms in thyroxine, since the last two, introduced in alkaline solution, must have entered the orlho positions to the free phenolic gromp.

For the actual synthesis of thyroxine the starting point was $3: 5$ diiodo-4-(4' methoxyphenoxy) benzaldehyde; but it could not be condensed directly with a-aminopropionic acid, since the necessary re. duction would displace the iodine atoms. Some success was attainod by condensing it with hydantoin, but far botter results were seen when hippuric acid was used. Tho resulting compound

$$
\mathrm{CH}_{3} \mathrm{O} \cdot \mathrm{C}_{6} \mathrm{H}_{4} \cdot \mathrm{O} \cdot \mathrm{C}_{6} \mathrm{H}_{2} \mathrm{I}_{2} \cdot \mathrm{CH}:\left(\mathrm{C}_{3} \mathrm{O}_{2} \mathrm{~N}\right): \mathrm{C}_{6} \mathrm{H}_{5}
$$

was then converted into the a-bonzoylamino cinnamic ester:

$\mathrm{CH}_{3} \mathrm{O} \cdot \mathrm{C}_{6} \mathrm{H}_{4} \cdot \mathrm{O} \cdot \mathrm{C}_{6} \mathrm{H}_{2} \mathrm{I}_{2} \cdot \mathrm{CH}: \mathrm{C}\left(\mathrm{NH} . \mathrm{CO}, \mathrm{C}_{6} \mathrm{H}_{5}\right) \mathrm{COOLt}$,

which, on boiling with hydriodic acid and red phos. phorus, underwent dernethylation and conversion of the side-chain into $a$-aminopropionic acid. The final stage of iodination in ammoniacal solution led to the uptake of two iodine atoms and the production of a compound identical in its chemical and physiological properties with natural thyroxine.

These two syntheses, then, establish finally the constitution of thyroxine. That the synthetic product has the same physiological properties as that isolated from the thyroid gland is shown in an appendix by D. M. Lyon : the basal metabolic rate of two cases of myxœedema was raised from about -40 per cent. to normal in the course of a week by three or four intravenous injections of $4-5 \mathrm{mgm}$. of the synthetic product on alternate days. These effects are quantita. tively similar to those reported for natural thyroxine.

There can be no doubt, then, as to the identity of the artificial and natural thyroxines, and we can congratulate the authors on bringing their resoarch to a successful conclusion.

\section{The Cofkle Industry in Great Britain.}

( UR knowledge of the edible billfish of British coasts has been extendepl by Mr. F. S. Wright in his "Report on thd Cockle Beds and the Cockle Industry of England and Wales" (Fishery Investigations, Series 2, Vol. 9, No. 5, 1926. London: H.M. Stationery Office. 3s. net). Not only are his own investigations on the habits, bionomics, and growth of cockles of great value, but he has also done a great service by bringing together a mass of information on the subject which has hitherto been very scattered.

The economic value of the cockle is considerable, and its potontial value even greater. Under the best conditions, when living in wet stable sand, cockles occur in vast numbers in comparatively small areas. Mr. Wright estimated that in one bed in the Llan- rhidian Sands in South Wales, having an area of some 320 acres, there were present about four hundred and sixty-two million cockles of all sizes, the average number in each square metre being 357. A very interesting point brought out in the paper is that in some localities there are definite beds of young cockles which contain a dense population. As the cockles grow, many are forced to the surface, and these are then distributed over the general surface of the beds by the action of waves and currents. Though the enemies of the cocklo include starfish, boring gastropods, gulls, and certain fish, the greatest danger to the beds comes from frost, storms, and currents, which may destroy great numbers of cockles in the winter months. The cockle gatherers themselves do

No. 3013, Vor, 120] 